\begin{tabular}{|l|l|l||}
\hline \multicolumn{2}{|c|}{ PublisherInfo } \\
\hline \hline PublisherName & $:$ & BioMed Central \\
\hline \hline PublisherLocation & $:$ & London \\
\hline \hline PublisherImprintName & $:$ & BioMed Central \\
\hline \hline
\end{tabular}

\title{
Controlling CFTR protein folding
}

\begin{tabular}{|l|l|l||}
\hline \multicolumn{2}{|c|}{ ArticleInfo } \\
\hline \hline ArticleID & $:$ & 4448 \\
\hline \hline ArticleDOI & $:$ & $10.1186 /$ gb-spotlight-20020411-01 \\
\hline \hline ArticleCitationID & $:$ & spotlight-20020411-01 \\
\hline \hline ArticleSequenceNumber & $:$ & 114 \\
\hline \hline ArticleCategory & $:$ & Research news \\
\hline ArticleFirstPage & $:$ & 1 \\
\hline \hline ArticleLastPage & $:$ & 2 \\
\hline \hline & & RegistrationDate : 2002-4-11 \\
\hline ArticleHistory & $:$ & OnlineDate \\
\hline \hline ArticleCopyright & $:$ & BioMed Central Ltd2002-11 \\
\hline \hline ArticleGrants & $:$ & \\
\hline \hline ArticleContext & $:$ & 130593311 \\
\hline \hline
\end{tabular}




\section{Tudor Toma}

Email: t.toma@ic.ac.uk

The mechanism by which a linear sequence of amino acids controls the folding of a protein into its unique three-dimensional structure remains incompletely understood. In the April 8 online edition Nature Structural Biology, Christian Wigley and colleagues from University of Texas Southwestern Medical Center, Dallas, show that a protein sequence can encode the native structure by preventing the formation of a misfolded structure.

Wigley et al. observed that a proline residue in the center of the third transmembrane helix of the cystic fibrosis transmembrane conductance regulator promotes correct folding by disfavoring alternate conformations. A genome-wide sequence analysis of transmembrane domains revealed a correlation between certain residues and proline, supporting the idea that this mechanism is a general one (Nat Struct Biol 2002, DOI: 10.1038/nsb784).

"Incorporation by nature of such 'negative folding determinants', aimed at preventing the formation of off-pathway structures, represents an additional mechanism by which folding information is encoded within the evolved sequences of proteins", concluded the authors.

\section{References}

1. Wigley WC, Corboy MJ, Cutler TD, Thibodeau PH, Oldan J, Lee MG, Rizo J, Hunt JF, Thomas PJ: A protein sequence that can encode native structure by disfavoring alternate conformations. Nat Struct Biol 2002, DOI: 10.1038/nsb784., [http://www.nature.com/nsb/]

2. University of Texas Southwestern Medical Center, [http://www3.utsouthwestern.edu/] 